\title{
Facts and Fiction: The Impact of Hypothermia on Molecular Mechanisms following Major Challenge
}

\author{
Michael Frink, ${ }^{1}$ Sascha Flohé, ${ }^{2}$ Martijn van Griensven, ${ }^{3}$ \\ Philipp Mommsen, ${ }^{1}$ and Frank Hildebrand ${ }^{1}$ \\ ${ }^{1}$ Trauma Department, Hannover Medical School, Carl-Neuberg-Straße 1, 30625 Hannover, Germany
${ }^{2}$ Department of Trauma and Hand Surgery, Heinrich Heine University Hospital, Moorenstraße 5, 40225 Düsseldorf, Germany
${ }^{3}$ Department for Experimental Trauma Surgery, Technical University of Munich, Ismaningerstraße 22, 81675 München, Germany
}

Correspondence should be addressed to Michael Frink, Michaelfrink@web.de

Received 17 November 2011; Accepted 2 January 2012

Academic Editor: Loek Leenen

Copyright (c) 2012 Michael Frink et al. This is an open access article distributed under the Creative Commons Attribution License, which permits unrestricted use, distribution, and reproduction in any medium, provided the original work is properly cited.

\begin{abstract}
Numerous multiple trauma and surgical patients suffer from accidental hypothermia. While induced hypothermia is commonly used in elective cardiac surgery due to its protective effects, accidental hypothermia is associated with increased posttraumatic complications and even mortality in severely injured patients. This paper focuses on protective molecular mechanisms of hypothermia on apoptosis and the posttraumatic immune response. Although information regarding severe trauma is limited, there is evidence that induced hypothermia may have beneficial effects on the posttraumatic immune response as well as apoptosis in animal studies and certain clinical situations. However, more profound knowledge of mechanisms is necessary before randomized clinical trials in trauma patients can be initiated.
\end{abstract}

\section{Introduction}

A great number of patients with major injuries [1-3] suffer from accidental hypothermia ranging from 12 to $66 \%$ $[4,5]$. In the current literature, multiple classifications using different definitions for hypothermia are described. In most classifications, hypothermia is defined as a core temperature below $35^{\circ} \mathrm{C}$. Since an increase of mortality has been demonstrated below a core temperature of $34^{\circ} \mathrm{C}$ in patients with multiple injuries, this temperature threshold seems to be critical in trauma patients and therefore a modified definition is reasonable [6]. Thereby, the extent of hypothermia correlates with the overall injury severity and is increased by pelvic or abdominal surgery [7]; furthermore, hypothermic polytrauma patients suffer from an increased incidence of posttraumatic complications $[2,4,8-10]$ as well as a an increased mortality $[2,8,11]$.

Depending on its origin, three entities of hypothermia are known: endogenous, induced, and accidental hypothermia.

Endogenous hypothermia results from a metabolic dysfunction with a decreased heat production (e.g., hypothyreodism, hypoglycaemia, hypoadrenalism) or a disturbed thermoregulation (e.g., intracranial tumor, degenerative neurologic disorders).

Accidental hypothermia is characterized by an unintentional decrease of the core temperature due to exposure to a cold environment without a thermoregulative dysfunction [12]. This can be aggravated by therapeutic interventions. The infusion of cold fluids as, for example, 21 of crystalloids $\left(18^{\circ}\right)$ decreases core temperatures about $0.6^{\circ} \mathrm{C}$ [13]. In addition, a reduced oxygen supply with an anaerobic state decreases the amount of adenosine trisphosphate (ATP) and subsequent heat production. Furthermore, the application of anaesthetics and skeletal muscle relaxants prevents shivering and vasoconstriction and therefore advances heat loss.

While the first two entities do not play a major role after trauma, accidental hypothermia is common in trauma patients as well as patients undergoing major surgery $[4,5]$. In contrast to accidental hypothermia that needs to be addressed in the treatment of severely injured patients due to its detrimental effects, induced hypothermia is commonly used, that is, in elective cardiac surgery [14]. In addition there exists a strong recommendation for the induction of hypothermia after cardiopulmonary reanimation, and 
there exists a growing body of evidence that suggests the application of hypothermia after blunt brain injury. Some articles were published regarding the influence of hypothermia in context of elective surgery but also on the posttraumatic immune response in animal models. However, an overview about the influence of hypothermia on the humeral and cellular immune response with special focus on apoptosis is missing. This paper outlines the molecular mechanisms by which hypothermia influences apoptosis as well as the immune response following severe trauma and major surgery.

\section{Apoptosis}

In general, cell death following hemorrhage and ischemia occurs either as necrosis of affected cells or as a complex process of programmed cell death called apoptosis. In contrast, necrosis represents the premature death of cells caused by external factors, that is, trauma, infections, or exposure to toxins.

Apoptosis is associated with a cascade of enzymatic reactions in which proteolytic caspase enzymes play a major role. Apoptosis could be initiated either in an extrinsic or intrinsic way [60]. The extrinsic way is characterized by the interaction of ligands (e.g., TNF- $\alpha$ ) with "death receptors" on the cell surface (e.g., CD95) activating the enzymatic cascade by caspase-8 [61]. The intrinsic activation of apoptosis is triggered by tumor suppressing factors (e.g., p53) resulting in an increased expression of proapoptotic factors of the bcl-2 family (e.g., bax, bad) and an increased mitochondrial release of cytochrome-c [62]. Binding Apaf-1 (apoptotic protease activating factor) cytochrome-c activates the apoptotic cascade via caspase- $9[63,64]$. Finally, programmed cell death is mediated by "effector caspases," especially caspase- 3 , in both ways of apoptotic activation. Besides the proteins of the bcl-2 family (antiapoptotic bcl-2; proapoptotic bax and bad), the apoptotic process is regulated by Mitogen-activated protein kinases (MAP-kinases) like extracellularsignal-regulated kinase $1 / 2$ (ERK 1/2), cJun N-terminal protein kinase 1/2 (JNK 1/2), and p38 MAP-kinase. Additionally, other pathways involving Phosphatidylinositol-3 kinases (PI3K) generating phosphatidylinositol-3,4,5-trisphosphate (PI-3,4,5-P(3)) and other phospholipids interacting with Akt are known to play an important role in regulating cell survival [65]. Furthermore, besides kinases the transcription factor NF-kappaB regulates cellular apoptotic programs [66].

In various studies, hypothermia was shown to prevent additional tissue injury by interrupting both, the intrinsic, and extrinsic apoptotic pathway [15, 67-70]. Interestingly, hypothermia seems to affect the very early steps in the apoptotic process including inhibition of activation of caspase enzymes, preserving mitochondrial function and decreased overload of excitatory transmitters. In contrast, apoptosis occurs relatively late following tissue challenge but it was shown that the process continues for up to 3 days [70-72]. Due to the delay of the apoptotic process, modulation of the apoptotic cascade could serve as a therapeutic target in early stages of polytrauma management after the initial resuscitation process in which the patient is stabilized with the aim to prevent additional damage. In this context, it is of special importance that the rate of apoptosis in neutrophils is dramatically decreased in multiple trauma patients [73].

2.1. In Vitro Studies. Cultured hepatocytes showed suppressed FAS-mediated apoptosis detected by a decreased mitochondrial damage following moderate hypothermia. Besides an attenuated cytochrome-c release, hypothermia suppressed the activation of caspase-7 and -9 [74]. This data suggests potential organ protective effects of hypothermia regarding apoptosis, which were confirmed in various animal models. On the other hand, murine neutrophils revealed a reduced spontaneous and $\mathrm{TNF} \alpha$-induced apoptosis under mild hypothermia of $35^{\circ} \mathrm{C}$ [75]. This fact could result in a prolonged exposure to activated neutrophils after trauma resulting in secondary organ damage.

2.2. Experimental Animal and Clinical Studies. Profound hypothermia was not only shown to preserve Akt in cardiomyocytes and inhibit caspase- 3 activation but also activate antiapoptotic proteins such as bcl-2 in an experimental model of hemorrhagic shock [19] and ischemic insult [20]. In ische$\mathrm{mia} /$ reperfusion injury, hypothermia reversed activation of apoptosis stimulating fragment (FAS)/caspase- 8 , the increase of bax (an proapoptotic protein), and decrease of bcl-2 in endothelial cells [16]. This was accompanied by an inhibition of JNK 1/2 activation via MKP-1 induction [16]. Following ischemia and reperfusion, isolated cardiomyocytes showed increased Phospho-Akt levels associated with attenuation of reactive oxygen species production, which was blocked by Akt but not cGMP inhibition [76]. Additionally, hypothermia was associated with downregulation of the TNF receptor (TNFR) 1 and its proapoptotic ligand FAS in rat cerebral cortices following a moderate fluid percussion model of traumatic brain injury [77].

Most of the clinical studies regarding the influence of hypothermia on apoptosis are limited to ischemic injuries following cardiac arrest or brain ischemia [78, 79].

In summary, there is clear evidence that hypothermia reduces ischemic neuronal apoptosis in global cerebral ischemia as a result of attenuated p53 expression and increased bcl-2 release [78]. Information regarding multiple injuries is not available to date. The effects of hypothermia on apoptosis are summarized in Table 1.

\section{Immune System}

3.1. Humoral Inflammatory Response. Immune response following major surgery or trauma consists of a complex set of pro- and anti-inflammatory reactions in order to restore homeostasis. The balance or imbalance of the pro- and antiinflammatory immune response in part influences the clinical course. Whereas predominance of the pro-inflammatory response leads to the Systemic Inflammatory Response Syndrome (SIRS), the anti-inflammatory reaction also named as compensatory anti-inflammatory response syndrome (CARS) might result in immune suppression with an enhanced risk of infectious complications. SIRS as well as 
TABLE 1: Effects of hypothermia on apoptosis.

\begin{tabular}{|c|c|c|c|c|}
\hline Authors & Study design & Insult & $\begin{array}{c}\text { Degree of } \\
\text { hypothermia }\end{array}$ & Effects \\
\hline $\mathrm{Xu}$ et al. [15] & In vitro study (mouse neurons) & $\begin{array}{l}\text { Apoptosis using serum } \\
\text { deprivation }\end{array}$ & $33^{\circ} \mathrm{C}$ & $\begin{array}{l}\text { caspase-3/8/9 } \downarrow \text {, cytochrome-c } \downarrow \text {, } \\
\text { JNK } \downarrow \text { (no effect on bcl-2, bax) }\end{array}$ \\
\hline Yang et al. [16] & In vitro study (HUVEC**) & $\begin{array}{l}\text { Ischemia using } \\
\text { oxygen-glucose } \\
\text { deprivation }\end{array}$ & $33^{\circ} \mathrm{C}$ & caspase-3/8 $\downarrow$, bcl- $2 \uparrow$, bax $\downarrow$, JNK $\downarrow$ \\
\hline Pastuszko et al. [17] & Experimental study (piglet neurons) & Ischemia & $33^{\circ} \mathrm{C}$ & $\begin{array}{c}\text { caspase- } 3 \downarrow \text {, bax } \downarrow \text { (no effect on } \\
\text { bcl- } 2 \text { ) }\end{array}$ \\
\hline Sahin et al. [18] & Experimental study (rat neurons) & Ischemia & $34^{\circ} \mathrm{C}$ & caspase-3/9 $\downarrow$, bcl- $2 \uparrow$, bax $\downarrow$ \\
\hline Shuja et al. [19] & $\begin{array}{c}\text { Experimental study (rat cardiac } \\
\text { tissue) }\end{array}$ & Hemorrhage & $15^{\circ} \mathrm{C}$ & bcl- $2 \uparrow$ \\
\hline Xiong et al. [20] & Experimental study (rat neurons) & Ischemia & $32-33^{\circ} \mathrm{C}$ & caspase- $3 \downarrow$, bcl- $2 \uparrow$ \\
\hline
\end{tabular}

${ }^{*}$ Human umbilical vein endothelial cells.

TABLE 2: Inflammatory cytokines.

\begin{tabular}{|c|c|c|c|}
\hline & Induction & Synthesis & Effects \\
\hline$T N F-\alpha$ & $\begin{array}{l}\text { hemorrhage, hypoxia, } \\
\text { ischemia, endotoxine }\end{array}$ & $\begin{array}{l}\text { macrophages, monocytes, } \\
\text { T-lymphocytes }\end{array}$ & $\begin{array}{l}\text { primary, proinflammatory cytokine } \\
\text { IL- } 1 \beta \text { and IL- } 6 \text { expression } \\
\text { activation of coagulation } \\
\text { prostaglandine } E 2 \text {, steroid release }\end{array}$ \\
\hline$I L-1 \beta$ & $\begin{array}{c}\text { hemorrhage, hypoxia, } \\
\text { ischemia, endotoxine } \\
\text { C5a, TNF- } \alpha\end{array}$ & $\begin{array}{c}\text { macrophages, monocytes, } \\
\text { endothelial cells }\end{array}$ & $\begin{array}{l}\text { primary, pro-inflammatory cytokine } \\
\text { Synergistic effects with TNF- } \alpha\end{array}$ \\
\hline$I L-6$ & LPS, IL- $1 \beta$, TNF- $\alpha$ & $\begin{array}{c}\text { T-/B-lymphocytes, } \\
\text { monocytes, endothelial cells }\end{array}$ & $\begin{array}{l}\text { Secondary, pro-inflammatory cytokine } \\
\text { induction of acute phase proteins (e.g., CRP, PCT) } \\
\text { differentiation of lymphocytes } \\
\text { activation of von NK-cells and neutrophils } \\
\text { anti-inflammatory effect (IL- } 1 \beta \downarrow \text {, TNF- } \alpha \downarrow)\end{array}$ \\
\hline$I L-8$ & $\begin{array}{l}\text { IL- } 1 \beta \text {, TNF- } \alpha \text {, bacteria, } \\
\text { LPS, hypoxia }\end{array}$ & $\begin{array}{l}\text { T-lymphocytes, monocytes, } \\
\text { neutrophils, endothelial cells }\end{array}$ & $\begin{array}{l}\text { Secondary, pro-inflammatory cytokine } \\
\text { chemotactic effect on leukocytes }\end{array}$ \\
\hline$I L-10$ & $\begin{array}{l}\text { TNF- } \alpha \text {, IL- } 1 \beta \text {, endotoxine, } \\
\text { LPS, prostaglandine E2 }\end{array}$ & $\begin{array}{l}\text { T-/B-lymphocytes, } \\
\text { monocytes, macrophages }\end{array}$ & anti-inflammatory cytokine \\
\hline
\end{tabular}

immune suppression plays a decisive role in the development of sepsis and the Multiple Organ Dysfunction Syndrome (MODS) after trauma. Cytokines, released from various cell types including immunocompetent and intrinsic cells, regulate the specific and unspecific immune response. These mediators are detectable in the peripheral blood and several compartments like the lung and the liver. They serve not only as a marker of injury severity or outcome predictors but also as a tool for decision-making regarding timing of elective surgery during the clinical course $[80,81]$. The most important cytokines in this regard include TNF- $\alpha$, IL- $1 \beta$, IL6, IL-8, and IL-10 (Table 2). As another essential step of the systemic immune response, chemotactic cytokines, so-called chemokines (IL-8, MCP-1, MIP- $1 \alpha$, or MIP-1 $\beta$ ) mediate neutrophil infiltration into the affected tissue [82]. Thereby, extravasation of neutrophils is mediated by different adhesion molecules [83]. The initial neutrophil-endothelial interaction, so-called rolling, is mediated by members of the selectin family of adhesion molecules. Integrins (CD11/CD18) and immunoglobulin superfamily receptors (ICAM-1, VCAM-1, ELAM-1) are important for the following firm adhesion and cell diapedesis [84, 85]. In various experimental as well as clinical studies, an effect of hypothermia on the inflammatory response by altering the expression of pro- and anti-inflammatory cytokines, chemokines and adhesion molecules has been shown [38, 86-88].

In brain injury, cytokines can have neuroprotective as well as neurotoxic properties. There is profound evidence that an inadequate or disproportionate posttraumatic immune response not only increases the risk for brain cell injury but also the extent of damage [89-95]. In this process, the IL-1 family plays a pivotal role. Elevated levels of IL-1 as well as an increased expression of IL-1 mRNA were detected following experimental brain injury in rodents, respectively [96-100]. While IL-1 does not cause brain damage itself, injection of IL-1 increased cell death following various brain 
TABLE 3: Effects of hypothermia on inflammatory cytokines.

\begin{tabular}{|c|c|c|c|c|}
\hline Authors & Study design & Insult & Degree of hypothermia & Effects \\
\hline Zheng et al. [21] & Experimental study (piglets) & Ischemia & $18^{\circ} \mathrm{C}$ & TNF- $\alpha \downarrow$, IL-6 $\downarrow$ \\
\hline Sipos et al. [22] & Experimental study (pigs) & Ischemia & $19 / 24 / 30^{\circ} \mathrm{C}$ & No effect TNF- $\alpha$, IL-6, IL-10 \\
\hline Qing et al. [23] & Experimental study (pigs) & Ischemia & $20 / 28^{\circ} \mathrm{C}$ & TNF- $\alpha \downarrow$, IL-10 $\uparrow$ \\
\hline Meybohm et al. [24] & Experimental study (pigs) & Ischemia & $33^{\circ} \mathrm{C}$ & TNF- $\alpha \downarrow$, IL- $1 \beta \downarrow$, IL- $6 \downarrow$, IL-10 $\downarrow$ \\
\hline Su and $\mathrm{Li}[25]$ & Experimental study (pigs) & Ischemia & Not defined & TNF- $\alpha \downarrow$, IL-6 $\downarrow$ \\
\hline Lim et al. [26] & Experimental study (rats) & Inflammation & $27^{\circ} \mathrm{C}$ & IL- $1 \beta \downarrow$, IL-10 \\
\hline Fujimoto et al. [27] & Experimental study (rats) & Inflammation & $32^{\circ} \mathrm{C}$ & IL-6 $\downarrow$, IL-10 $\uparrow$ \\
\hline Stewart et al. [28] & Experimental study (mice) & Inflammation & $32^{\circ} \mathrm{C}$ & $\begin{array}{c}\text { IL-6 } \uparrow, \text { IL-10 } \uparrow \text {; no effect on TNF- } \alpha \text {, } \\
\text { IL- } 1 \beta\end{array}$ \\
\hline Kim et al. [29] & Experimental study (rats) & Hemorrhage & $27-30^{\circ} \mathrm{C}$ & IL-6 $\downarrow, \mathrm{IL}-10 \uparrow$ \\
\hline Gundersen et al. [30] & Experimental study (rats) & Hemorrhage & $32.5-33^{\circ} \mathrm{C}$ & IL- $6 \downarrow$, no effect on TNF- $\alpha$, IL-10 \\
\hline Beiser et al. [31] & Experimental study (mice) & Hemorrhage & $33^{\circ} \mathrm{C}$ & IL-6 $\downarrow$ \\
\hline Wagner et al. [32] & Experimental study (mice) & Septic shock & $27^{\circ} \mathrm{C}$ & IL-6 $\downarrow$ \\
\hline Vitarbo et al. [33] & Experimental study (rats) & Trauma (TBI) & $33^{\circ} \mathrm{C}$ & TNF- $\alpha \downarrow$ \\
\hline Morita et al. [34] & Experimental study (rats) & Trauma (Lung) & $34^{\circ} \mathrm{C}$ & TNF- $\alpha \downarrow$, IL- $6 \downarrow$, IL-10 $\uparrow$ \\
\hline Lee et al. [35] & Experimental study (rats) & $\begin{array}{l}\text { Hypothermia } \\
\text { (isolated) }\end{array}$ & $30^{\circ} \mathrm{C}$ & IL-2 $\downarrow$, IL-10 \\
\hline Qayumi et al. [36] & Experimental study (pigs) & $\begin{array}{l}\text { Lung } \\
\text { transplantation }\end{array}$ & $\begin{array}{l}\text { ex vivo preservation at } \\
4^{\circ} \mathrm{C}\end{array}$ & $\begin{array}{l}\text { No effect on TNF- } \alpha \text {, IL-2, IL-4, } \\
\text { IL-10, Thromboxan }\end{array}$ \\
\hline Shiozaki et al. [37] & Clinical study & Trauma (TBI) & $34^{\circ} \mathrm{C}$ & No effect onTNF- $\alpha$, IL-6, IL-10 \\
\hline Aibiki et al. [38] & Clinical study & Trauma (TBI) & $32-33^{\circ} \mathrm{C}$ & IL-6 $\downarrow$ \\
\hline
\end{tabular}

damage models [101-103]. The hypothesis that IL-1 increases brain damage is supported by experiments in which an IL-1 antagonist prevented cell death in experimental brain injury [102-105]. Similar results were observed following treatment with an IL-1 converting enzyme (ICE) inhibitor in cerebral ischemia [106]. Thus, modulation of cytokine release by hypothermia may serve as a therapeutic approach following major injury.

3.1.1. In Vitro Studies. Peripheral blood mononuclear cells stimulated with lipopolysaccharide (LPS) from healthy volunteers showed decreased TNF- $\alpha$ release, while release of IL1 and IL- 6 was delayed when incubated at $33^{\circ} \mathrm{C}$ as compared to incubation at $37^{\circ} \mathrm{C}$ [86]. In a similar study with human macrophages, early secretion of TNF- $\alpha$ and IL-6 was blunted and in human monocytes early IL- 6 and IL- $1 \beta$ secretion was decreased [107]. Additionally, a shift towards anti-inflammatory cytokines was detected in microglia cells following LPS treatment [108]. In contrast, hypothermia of $33^{\circ} \mathrm{C}$ raised the levels of IL- $1 \beta$, IL- 6 , and TNF- $\alpha$ produced by monocytes from healthy volunteers stimulated with LPS [109]. This controversial findings suggest diverse effects of hypothermia on different cell types.

3.1.2. Experimental Animal Models. In a rat model of acute hemorrhage, Gundersen et al. evaluated the effect of hypothermia on immune response and corresponding organ damage. Moderate hypothermia had an organ protective effect in liver and kidney, which was associated with a decreased release of IL- 6 as well as a reduction of reactive ox- ygen species [30]. In contrast, mild hypothermia did not affect systemic levels of IL-1, IL-6, and IL-10, while serum TNF- $\alpha$ levels were even increased following hemorrhagic shock suggesting different responses of cytokines or their respective sources [110].

In a study using a swine model of uncontrolled lethal hemorrhage, the authors were able to detect a decreased proinflammatory (IL-6) and an increased anti-inflammatory (IL-10) immune response following profound hypothermia. Furthermore, the potentially protective chaperone heat shock protein-70 (HSP 70) was preserved. The authors, therefore, concluded a beneficial modulation of the immune system due to hypothermia in this hemorrhage model [111].

Only a few publications investigated the anti-inflammatory effects of hypothermia in a combined trauma-hemorrhage setting. In a two-hit model consisting of a femoral fracture and hemorrhage, systemic IL-10 levels were elevated following mild hypothermia [44] confirming results from other experimental studies $[35,112,113]$. The increased antiinflammatory response induced by hypothermia was also associated with a conversion from Th-1 to Th-2 cytokine pattern [35].

In a nonbacterial-driven sepsis model using intraperitoneal lipopolysaccharide injection, hypothermia also induced elevated plasma IL-10 levels [114].

The effects of hypothermia on the release of inflammatory cytokines are presented in Table 3.

3.1.3. Clinical Studies. Experimental studies of traumatic brain injury, in which hypothermia decreased systemic 
TABLE 4: Effects of hypothermia on chemokines.

\begin{tabular}{|c|c|c|c|c|}
\hline Authors & Study design & Insult & Degree of hypothermia & Effects \\
\hline Dalen et al. [39] & In vitro study (human neurons) & $\begin{array}{l}\text { Ischemia using } \\
\text { oxygen-glucose } \\
\text { deprivation }\end{array}$ & $33^{\circ} \mathrm{C}$ & $\begin{array}{l}\text { No effect on IL-8, } \\
\text { MCP-1 }\end{array}$ \\
\hline Diestel et al. [40] & In vitro study (HUVEC*) & Inflammation & $17 / 32^{\circ} \mathrm{C}$ & IL- $8 \downarrow$, MCP- $1 \downarrow$ \\
\hline Sutcliffe et al. [41] & In vitro study $\left(\mathrm{HCEC}^{* *}\right)$ & Inflammation & $32^{\circ} \mathrm{C}$ & IL-8 $\downarrow$ \\
\hline Zheng et al. [21] & Experimental study (piglets) & Ischemia & $18^{\circ} \mathrm{C}$ & IL-8 $\downarrow$ \\
\hline Li et al. [42] & Experimental study (rats) & Ischemia & $32-33^{\circ} \mathrm{C}$ & MCP-1 $\downarrow$ \\
\hline Callaway et al. [43] & Experimental study (rats) & Ischemia & $33^{\circ} \mathrm{C}$ & $\begin{array}{l}\text { No effect on MCP-1 } \\
\text { and MIP- } 1 \alpha\end{array}$ \\
\hline Hildebrand et al. [44] & Experimental study (mice) & Hemorrhage & $27-30 / 30-33 / 33-35^{\circ} \mathrm{C}$ & MCP-1 $\downarrow$ \\
\hline Eggum et al. [45] & Clinical study & Surgery & $25 / 32^{\circ} \mathrm{C}$ & $\begin{array}{c}\text { RANTES and } \\
\text { MCP- } 1 \downarrow\end{array}$ \\
\hline Menasche et al. [46] & Clinical study & Surgery & $\sim 26^{\circ} \mathrm{C}$ & No effect on IL-8 \\
\hline
\end{tabular}

* human umbilical vein endothelial cells.

** human cerebral endothelial cells.

TABLE 5: Effects of hypothermia on adhesion molecules.

\begin{tabular}{|c|c|c|c|c|}
\hline Authors & Study design & Insult & Degree of hypothermia & Effects \\
\hline Haddix et al. [47] & In vitro study (HUVEC*) & Inflammation & $25^{\circ} \mathrm{C}$ & E-Selectin $\downarrow$ \\
\hline Sutcliffe et al. [41] & In vitro study (HCEC**) & Inflammation & $32^{\circ} \mathrm{C}$ & $\begin{array}{l}\text { No effect on ICAM-1, CD } 18 \\
\text { (Integrin) }\end{array}$ \\
\hline Frohlich et al. [48] & $\begin{array}{l}\text { In vitro study (human } \\
\text { leukocytes) }\end{array}$ & Inflammation & $33 / 35^{\circ} \mathrm{C}$ & $\begin{array}{c}\text { CD 11b (Mac-1) } \uparrow \text {, no effect on } \\
\text { CD62L (L-Selectin) }\end{array}$ \\
\hline Johnson et al. [49] & In vitro study (HUVEC*) & Hypothermia (isolated) & $25^{\circ} \mathrm{C}$ & E-Selectin $\downarrow$ \\
\hline Meybohm et al. [24] & Experimental study (pigs) & Ischemia & $33^{\circ} \mathrm{C}$ & ICAM- $1 \downarrow$ \\
\hline Callaway et al. [43] & Experimental study (rats) & Ischemia & $33^{\circ} \mathrm{C}$ & No effect on ICAM-1 \\
\hline Wang et al. [50] & Experimental (rats) & Ischemia & $33^{\circ} \mathrm{C}$ & ICAM- $1 \downarrow$ \\
\hline Deng et al. [51] & Experimental study (rats) & Ischemia/Inflammation & $33^{\circ} \mathrm{C}$ & ICAM- $1 \downarrow$ \\
\hline Hanusch et al. [52] & Experimental study (rats) & Hypothermia (isolated) & $\begin{array}{l}\text { Ex vivo storage after } \\
\text { flushing lungs with cold } \\
\text { fluid }\left(4^{\circ} \mathrm{C}\right)\end{array}$ & ICAM- $1 \downarrow$, VCAM- $1 \downarrow$, ELAM- 1 \\
\hline Choi et al. [53] & Experimental study (rats) & Ischemia & $33^{\circ} \mathrm{C}$ & ICAM- $1 \downarrow$ \\
\hline Menasche et al. [46] & Clinical study & Surgery & $\sim 26^{\circ} \mathrm{C}$ & No effect on P- und E-Selectin \\
\hline Boldt et al. [54] & Clinical study & Surgery & $27-28^{\circ} \mathrm{C}$ & $\begin{array}{l}\text { No effect on ICAM-1, VCAM-1, } \\
\text { ELAM-1 }\end{array}$ \\
\hline
\end{tabular}

* human umbilical vein endothelial cells.

** human cerebral endothelial cells.

cytokine levels, were confirmed by a clinical study showing a suppression in cytokine release associated with an improved outcome $[38,88]$. In cerebral trauma patients, hypothermia of $32-33^{\circ} \mathrm{C}$ suppressed systemic IL-6 levels, which was associated with an increased Glasgow outcome scale 6 months postinjury as compared to patients treated under normothermic conditions [38].

3.2. Adhesion Molecules and Chemokines. The effects of hypothermia on chemokine levels and the expression of adhesion molecules were investigated in experimental as well as clinical studies (Tables 4 and 5 ).

3.2.1. In Vitro Studies. In vitro studies of human umbilical vein endothelial cells showed decreased MCP-1 as well as
IL-8 levels under hypothermic conditions [40]. In contrast, no effect of hypothermia on ICAM-1 expression in human cerebral endothelial cells was shown under stress conditions [41]. In cultured human umbilical vein cells, hypothermia inhibited the transcription and expression but not the induction of E-selectin [49].

3.2.2. Experimental Animal Models and Clinical Studies. In a model of cerebral ischemia and reperfusion, mild hypothermia reduced local expression of MCP-1 [42]. The same finding could be confirmed in a murine multiple trauma model [44]. In another cerebral ischemia model, intraischemic as well as delayed hypothermia decreased ICAM-1 expression as well as intracerebral neutrophil infiltration [51]. 
In pediatric cardiopulmonary bypass ( $\mathrm{CPB}$ ) surgery, hypothermia reduced systemic levels of the chemokine regulated on activation normal $\mathrm{T}$ cell expressed and secreted (RANTES) and MCP-1 [45]. In contrast, no effect of hypothermia on MCP-1 levels was detected in a model of cardiac arrest in rats [43].

In transient focal cerebral ischemia, mild hypothermia reduced ICAM-1 expression, which was associated with reduced neutrophil and monocyte infiltration [50].

In contrast to experimental studies, circulating adhesion molecules were not altered by hypothermia in aortocoronary artery bypass grafting [54]. The effects of hypothermia on adhesion molecules are presented in Table 5.

In summary, there is evidence that induced hypothermia decreases pro-inflammatory cytokines as well as chemokines and adhesion molecules. Besides this, an increased anti-inflammatory cytokine response is observed in various trauma models. However, information of human studies is spare.

\subsection{Cellular Immune Response}

3.3.1. Experimental Studies. Hypothermia influences the cellular immune response, which was especially studied following brain injury. In various animal models, neutrophil and macrophage function was attenuated leading to a decreased extent of secondary brain injury and infarction size [115]. Furthermore, posttraumatic hypothermia decreased early and prolonged accumulation of neutrophils and myeloperoxidase activity suggesting hypothermia as a potential mechanism to modulate outcome [116]. These findings confirmed an earlier study of Toyoda et al. showing a decreased neutrophil infiltration following intraischemic hypothermia in a focal ischemia reperfusion injury [55], which was also shown after delayed hypothermia in another cerebral ischemia model [51].

Additionally, posttraumatic hypothermia reduced neutrophil accumulation on the injury site at $24 \mathrm{~h}$ in a model of spinal cord injury [57].

Although most studies were conducted in traumatic brain injury, similar findings were shown in other organs. Already in the 1980s, it was shown that hypothermia reduced local neutrophil infiltration in an experimental pleuritis model, while the number of circulating neutrophils was not affected [117]. Other studies suggest a hypothermia-induced decrease of circulating neutrophils after soft-tissue injury in piglets [118], supporting an older study with prolonged hypothermia of $29^{\circ} \mathrm{C}$ in pigs [119]. The reduced infiltration can be explained by a decrease of adhesion molecules due to hypothermia. However, phagocytosis of opsonised bacteria is even increased at a lower temperature suggesting a temperature-dependent activation of neutrophils [48].

Following major injuries, infiltrated neutrophils release proteolytic enzymes as well as free radicals causing tissue damage which may subsequently lead to organ dysfunction and failure. Hypothermia was able to reduce the amount of free radicals in ischemic brain injury. In contrast, hypothermia did not affect the formation of free radicals in a rat model of hemorrhagic shock [120-122]. The reduced num- ber of free radicals is of great benefit since the capacity of antioxidative mechanisms is limited. Interestingly, the prevention of free radical production is linearly linked to the temperature [123]. Most of free radicals following brain injury are synthesized by nitric oxide synthase and by deregulated mitochondrial electron transporters [124-127]. Thus, it was speculated that the prevention of release or synthesis of free radicals may be induced by preserved mitochondrial function [128]. Interestingly, mitochondrial function plays also a pivotal role in the development of apoptosis through inhibition of the caspase cascade activation. The essential role of the nitric oxide synthase was supported by another experiment, in which attenuation of acute lung injury by induced hypothermia following hemorrhagic shock was associated with less myeloperoxidase activity and decreased gene expression of iNOS. Furthermore, gene expression of heat shock protein (HSP-72), a molecular chaperone known to exert protective effects in ischemia-reperfusion injury, was detected in hypothermic but not in normothermic rats [29].

In contrast to these results, another study using a model of pressure-controlled hemorrhagic shock revealed no differences in serum-free 8-isoprostane (a marker of lipid peroxidation by free radicals) between the two groups at either baseline or resuscitation time $1 \mathrm{hr}$ [120]. In a forebrain ischemia and recirculation model, hypothermia prevented production of hydroxyl radicals following hyperthermia [129]. In another study, postischemic leukotriene production a well as edema development was reduced $2 \mathrm{~h}$ but not $10 \mathrm{~min}$ following reperfusion [130]. The effects of hypothermia on the respiratory burst are summarized in Table 6 .

3.3.2. Clinical Studies. Controlled mild hypothermia had no effect on the number of circulating $\mathrm{T}$ lymphocytes in patients with severe brain injury [131]. A clinical study including infants and children with severe traumatic brain injury showed a preserved antioxidant reserve in cerebrospinal fluid, suggesting an attenuation of oxidative stress following hypothermia in severe brain injury [128].

\section{Functional Parameters}

4.1. Experimental Studies. Less neuron damage was detected at a temperature of $34^{\circ} \mathrm{C}$ following brain ischemia [132] confirming another study of thoracic aortic ischemia-reperfusion injury in which hypothermia prevented and delayed paralysis by preserving cells of the central nervous system [133]. In another study, a beneficial long-term effect of mild $\left(35^{\circ} \mathrm{C}\right)$ and moderate $\left(32^{\circ} \mathrm{C}\right)$ hypothermia was detected after spinal cord ischemia and reperfusion until 28 days following the injury [134].

In a rat model of ischemia/reperfusion of the lower extremity, local hypothermia protected skeletal muscle from capillary leakage, which was prevented after treatment with heme oxygenase and nitric oxide synthase inhibitors [135].

Hypothermia not only prevents damage on site of injury but also distant organ damage. In mesenteric ischemia-reperfusion injury, remote lung injury was prevented as measured by leukocyte trafficking, alveolar hemorrhage, and 
TABLE 6: Effects of hypothermia on proteins/molecules associated with the production of reactive oxygen species.

\begin{tabular}{|c|c|c|c|c|}
\hline Authors & Study design & Insult & Degree of hypothermia & Effects \\
\hline Toyoda et al. [55] & Experimental study (rats) & Ischemia & $30^{\circ} \mathrm{C}$ & MPO $\downarrow$ \\
\hline Lim et al. [26] & Experimental study (rats) & Inflammation & $27^{\circ} \mathrm{C}$ & MPO $\downarrow$ \\
\hline Kim et al. [29] & Experimental study (rats) & Hemorrhage & $27-30^{\circ} \mathrm{C}$ & $\begin{array}{c}\text { Malondialdehyde } \\
\text { (TBARS) } \downarrow, \text { MPO } \downarrow \text {, iNOS } \\
\downarrow, \text { NO } \downarrow\end{array}$ \\
\hline Duz et al. [56] & Experimental study (rats) & Trauma (spinal cord) & $27-29^{\circ} \mathrm{C}$ & Malondialdehyde (TBARS) \\
\hline Chatzipanteli et al. [57] & Experimental study (rats) & Trauma (spinal cord) & $32^{\circ} \mathrm{C}$ & MPO $\downarrow$ \\
\hline Grezzana Filho et al. [58] & Experimental study (rats) & Ischemia & $26^{\circ} \mathrm{C}$ & $\begin{array}{l}\text { Malondialdehyde } \\
\text { (TBARS) } \downarrow,\end{array}$ \\
\hline Qayumi et al. [36] & Experimental study (pigs) & Lung transplantation & $\begin{array}{c}\text { ex vivo preservation at } 4^{\circ} \mathrm{C} \\
\text { hypothermia) }\end{array}$ & $\begin{array}{l}\text { No effect on } \\
\text { Superoxide-Dismutase, } \\
\text { GR }^{*}, \mathrm{GP}^{* *}\end{array}$ \\
\hline Hsu et al. [59] & Experimental study (rats) & Heatstroke & $\begin{array}{l}\text { Perfusion with cold fluid } \\
\qquad\left(4^{\circ} \mathrm{C}\right)\end{array}$ & $\begin{array}{c}\text { Malondialdehyde (TBARS) } \\
\downarrow \text { Glutathione } \uparrow, \text { GP }^{* *} \uparrow, \\
\text { GR* } \uparrow \\
\text { Superoxid-Dismutase } \uparrow\end{array}$ \\
\hline Eggum et al. [45] & Clinical study & Surgery & $25 / 32^{\circ} \mathrm{C}$ & No effect on MPO \\
\hline
\end{tabular}

increased BAL protein and wet/dry ratios [136]. These results confirmed another study using a hepatic model of ischemia/reperfusion injury, in which hypothermia reduced the associated lung injury [137].

In a rat hemorrhagic shock model, mild hypothermia $\left(34^{\circ} \mathrm{C}\right)$ improved survival associated with modulation of the immune response [110].

4.2. Clinical Studies. Clinical studies are mainly focused on patients with traumatic brain injury. In general, there is a gap between experimental studies and clinical experience. In a multicenter study of 392 patients with severe head injuries, hypothermia of $33^{\circ} \mathrm{C}$ did not influence outcome. In 5 meta-analyses, conflicting results regarding outcome were shown [138-142]. Only 2 of them [141, 142] described a marginal benefit regarding mortality and neurological outcome. Patients with elevated intracranial pressure seem to be the cohort with the most benefit of hypothermia [141]. Regarding these controversial results, in current guidelines hypothermia is recommended as a level III treatment option [143].

\section{Cooling Rewarming Procedure}

5.1. Experimental Studies. Only few experimental studies investigated the effect of different cooling and rewarming strategies.

Hypothermia at time of occlusion decreased infarct size in a myocardial ischemia-reperfusion injury supporting the results showing an increased cellular tolerance to ischemia under hypothermic conditions [144]. These results suggest starting hypothermia as soon as the hemodynamic and hemostaseological parameters were stabilized. In contrast, there is consistent evidence that rapid rewarming reverses the beneficial effects of induced hypothermia in traumatic brain injury [145]. Furthermore, gradual rewarming improved survival and attenuated remote acute lung injury after intestinal ischemia and reperfusion injury as compared to speed rewarming [146]. The mechanism behind this phenomenon is only partly understood. Considering the current literature, it seems likely that abrogation of the beneficial effects is associated with ATP depletion, energy failure, and consecutive mitochondrial dysfunction [145]. To date, detailed knowledge about exact mechanisms in different rewarming strategies is lacking.

5.2. Clinical Studies. The European Resuscitation Council recommends early hypothermia $\left(32-34^{\circ} \mathrm{C}\right)$ for $12-24$ hours following cardiac arrest and a slow rewarming procedure with $0.25-0.5^{\circ} \mathrm{C}$ per hour avoiding hyperthermia [147]. In a clinical study in 57 hypothermic patients, continuous arteriovenous rewarming resulted in less fluid requirement and less mortality as compared to standard rewarming procedures [11].

In summary, there is only minor understanding of the rewarming process but slow rewarming is recommended based on mostly experimental studies.

\section{Perspective}

Before induced hypothermia can be introduced in the clinical management of patients several limitations of the presented studies need to be considered. A potential limitation of all studies in which hypothermia is induced by a cardiopulmonary bypass machine is the fact that increase of cytokines may 
be due to the bypass procedure itself [111]. While numerous experimental as well as clinical studies regarding cardiac surgery, brain injury, or cardiac arrest are available information regarding hypothermia following major injuries is spare. Since there are still divergent results in experimental studies that are mostly limited to traumatic brain injury, the mechanisms by which hypothermia influences the posttraumatic immune response after multiple trauma need to be elucidated.

\section{Acknowledgments}

The authors are members of the study group "Hypothermia" of the German Trauma Association.

\section{References}

[1] J. S. Gregory, J. M. Bergstein, C. Aprahamian, D. H. Wittmann, and E. J. Quebbeman, "Comparison of three methods of rewarming from hypothermia: advantages of extracorporeal blood warming," Journal of Trauma, vol. 31, no. 9, pp. 1247-1251, 1991.

[2] G. K. Luna, R. V. Maier, E. G. Pavlin, D. Anardi, M. K. Copass, and M. R. Oreskovich, "Incidence and effect of hypothermia in seriously injured patients," Journal of Trauma, vol. 27, no. 9, pp. 1014-1018, 1987.

[3] S. Steinemann, S. R. Shackford, and J. W. Davis, "Implications of admission hypothermia in trauma patients," Journal of Trauma, vol. 30, no. 2, pp. 200-202, 1990.

[4] J. S. Gregory, L. Flancbaum, M. C. Townsend, C. T. Cloutier, and O. Jonasson, "Incidence and timing of hypothermia in trauma patients undergoing operations," Journal of Trauma, vol. 31, no. 6, pp. 795-798, 1991.

[5] F. Hildebrand, M. van Griensven, P. Giannoudis et al., "Impact of hypothermia on the immunologic response after trauma and elective surgery," Surgical Technology International, vol. 14, pp. 41-50, 2005.

[6] B. J. Tsuei and P. A. Kearney, "Hypothermia in the trauma patient," Injury, vol. 35, no. 1, pp. 7-15, 2004.

[7] H. B. Stoner, "Responses to trauma: fifty years of ebb and flow," Circulatory Shock, vol. 39, no. 4, pp. 316-319, 1993.

[8] G. J. Jurkovich, W. B. Greiser, A. Luterman, and P. W. Curreri, "Hypothermia in trauma victims: an ominous predictor of survival," Journal of Trauma, vol. 27, no. 9, pp. 1019-1024, 1987.

[9] R. S. Martin, P. D. Kilgo, P. R. Miller, J. J. Hoth, J. W. Meredith, and M. C. Chang, "Injury-associated hypothermia: an analysis of the 2004 National Trauma Data Bank," Shock, vol. 24, no. 2, pp. 114-118, 2005.

[10] G. J. Beilman, J. J. Blondet, T. R. Nelson et al., "Early hypothermia in severely injured trauma patients is a significant risk factor for multiple organ dysfunction syndrome but not mortality," Annals of Surgery, vol. 249, no. 5, pp. 845-850, 2009.

[11] L. M. Gentilello, G. J. Jurkovich, M. S. Stark, S. A. Hassantash, and G. E. O'Keefe, "Is hypothermia in the victim of major trauma protective or harmful? A randomized, prospective study," Annals of Surgery, vol. 226, no. 4, pp. 439-447, 1997.

[12] L. D. Britt, W. H. Dascombe, and A. Rodriguez, "New horizons in management of hypothermia and frostbite injury,"
Surgical Clinics of North America, vol. 71, no. 2, pp. 345-370, 1991.

[13] M. Hohlrieder, M. Kaufmann, M. Moritz, and V. Wenzel, "Management of accidental hypothermia," Anaesthesist, vol. 56, no. 8, pp. 805-811, 2007.

[14] F. E. Kelly and J. P. Nolan, "The effects of mild induced hypothermia on the myocardium: a systematic review," Anaesthesia, vol. 65, no. 5, pp. 505-515, 2010.

[15] L. Xu, M. A. Yenari, G. K. Steinberg, and R. G. Giffard, "Mild hypothermia reduces apoptosis of mouse neurons in vitro early in the cascade," Journal of Cerebral Blood Flow and Metabolism, vol. 22, no. 1, pp. 21-28, 2002.

[16] D. Yang, S. Guo, T. Zhang, and H. Li, "Hypothermia attenuates ischemia/reperfusion-induced endothelial cell apoptosis via alterations in apoptotic pathways and JNK signaling," FEBS Letters, vol. 583, no. 15, pp. 2500-2506, 2009.

[17] P. Pastuszko, A. Pirzadeh, E. Reade et al., "The effect of hypothermia on neuronal viability following cardiopulmonary bypass and circulatory arrest in newborn piglets," European Journal of Cardiothoracic Surgery, vol. 35, no. 4, pp. 577-581, 2009.

[18] S. Sahin, T. Alkan, S. G. Temel, K. Tureyen, S. Tolunay, and E. Korfali, "Effects of citicoline used alone and in combination with mild hypothermia on apoptosis induced by focal cerebral ischemia in rats," Journal of Clinical Neuroscience, vol. 17, no. 2, pp. 227-231, 2010.

[19] F. Shuja, M. Tabbara, Y. Li et al., "Profound hypothermia decreases cardiac apoptosis through AKT survival pathway," Journal of the American College of Surgeons, vol. 209, no. 1, pp. 89-99, 2009.

[20] M. Xiong, G. Q. Cheng, S. M. Ma, Y. Yang, X. M. Shao, and W. H. Zhou, "Post-ischemic hypothermia promotes generation of neural cells and reduces apoptosis by Bcl-2 in the striatum of neonatal rat brain," Neurochemistry International, vol. 58, no. 6, pp. 625-633, 2011.

[21] J. H. Zheng, B. T. Gao, Z. M. Jiang, X. Q. Yu, and Z. W. $\mathrm{Xu}$, "Evaluation of early macrophage activation and NFkappaB activity in pulmonary injury caused by deep hypothermia circulatory arrest: An experimental study," Pediatric Cardiology, vol. 31, no. 2, pp. 215-221, 2010.

[22] W. Sipos, C. Duvigneau, F. Sterz et al., "Changes in interleukin-10 mRNA expression are predictive for 9-day survival of pigs in an emergency preservation and resuscitation model," Resuscitation, vol. 81, no. 5, pp. 603-608, 2010.

[23] M. Qing, J. F. Vazquez-Jimenez, B. Klosterhalfen et al., "Influence of temperature during cardiopulmonary bypass on leukocyte activation, cytokine balance, and post-operative organ damage," Shock, vol. 15, no. 5, pp. 372-377, 2001.

[24] P. Meybohm, M. Gruenewald, K. D. Zacharowski et al., "Mild hypothermia alone or in combination with anesthetic postconditioning reduces expression of inflammatory cytokines in the cerebral cortex of pigs after cardiopulmonary resuscitation," Critical Care, vol. 14, article R21, 2010.

[25] Z. Y. Su and C. S. Li, "The influence of hypothermia therapy on enzymology and pathology of lung after cardiac arrest," Zhongguo Wei Zhong Bing Ji Jiu Yi Xue, vol. 22, no. 2, pp. 8588,2010 .

[26] C. M. Lim, M. S. Kim, J. J. Ahn et al., "Hypothermia protects against endotoxin-induced acute lung injury in rats," Intensive Care Medicine, vol. 29, no. 3, pp. 453-459, 2003.

[27] K. Fujimoto, M. Fujita, R. Tsuruta et al., "Early induction of moderate hypothermia suppresses systemic inflammatory cytokines and intracellular adhesion molecule- 1 in rats with 
caerulein-induced pancreatitis and endotoxemia," Pancreas, vol. 37, no. 2, pp. 176-181, 2008.

[28] C. R. Stewart, J. P. Landseadel, M. J. Gurka, and K. D. Fairchild, "Hypothermia increases interleukin-6 and interleukin-10 in juvenile endotoxemic mice," Pediatric Critical Care Medicine, vol. 11, no. 1, pp. 109-116, 2010.

[29] K. Kim, W. Kim, J. E. Rhee et al., "Induced hypothermia attenuates the acute lung injury in hemorrhagic shock," Journal of Trauma, vol. 68, no. 2, pp. 373-381, 2010.

[30] Y. Gundersen, P. Vaagenes, A. Pharo, E. T. Valo, and P. K. Opstad, "Moderate hypothermia blunts the inflammatory response and reduces organ injury after acute haemorrhage," Acta Anaesthesiologica Scandinavica, vol. 45, no. 8, pp. 9941001, 2001.

[31] D. G. Beiser, H. Wang, J. Li et al., "Plasma and myocardial visfatin expression changes are associated with therapeutic hypothermia protection during murine hemorrhagic shock/resuscitation," Resuscitation, vol. 81, no. 6, pp. 742$748,2010$.

[32] F. Wagner, K. Wagner, S. Weber et al., "Inflammatory effects of hypothermia and inhaled H2S during resuscitated, hyperdynamic murine septic shock," Shock, vol. 35, no. 4, pp. 396-402, 2011.

[33] E. A. Vitarbo, K. Chatzipanteli, K. Kinoshita, J. S. Truettner, O. F. Alonso, and W. D. Dietrich, "Tumor necrosis factor alpha expression and protein levels after fluid percussion injury in rats: the effect of injury severity and brain temperature," Neurosurgery, vol. 55, no. 2, pp. 416-424, 2004.

[34] Y. Morita, S. Oda, T. Sadahiro et al., "The effects of body temperature control on cytokine production in a rat model of ventilator-induced lung injury," Cytokine, vol. 47, no. 1, pp. 48-55, 2009.

[35] S. L. Lee, F. D. Battistella, and K. Go, "Hypothermia induces T-cell production of immunosuppressive cytokines," Journal of Surgical Research, vol. 100, no. 2, pp. 150-153, 2001.

[36] A. K. Qayumi, M. Nikbakht-Sangari, D. V. Godin et al., “The relationship of ischemia-reperfusion injury of transplanted lung and the up-regulation of major histocompatibility complex II on host peripheral lymphocytes," Journal of Thoracic and Cardiovascular Surgery, vol. 115, no. 5, pp. 978-989, 1998.

[37] T. Shiozaki, T. Hayakata, M. Taneda et al., "A multicenter prospective randomized controlled trial of the efficacy of mild hypothermia for severely head injured patients with low intracranial pressure," Journal of Neurosurgery, vol. 94, no. 1, pp. 50-54, 2001.

[38] M. Aibiki, S. Maekawa, S. Ogura, Y. Kinoshita, N. Kawai, and S. Yokono, "Effect of moderate hypothermia on systemic and internal jugular plasma IL-6 levels after traumatic brain injury in humans," Journal of Neurotrauma, vol. 16, no. 3, pp. 225-232, 1999.

[39] M. L. Dalen, E. Froyland, O. D. Saugstad, T. E. Mollnes, and T. Rootwelt, "Post-hypoxic hypothermia is protective in human NT2-N neurons regardless of oxygen concentration during reoxygenation," Brain Research, vol. 1259, pp. 80-89, 2009.

[40] A. Diestel, J. Roessler, F. Berger, and K. R. L. Schmitt, "Hypothermia downregulates inflammation but enhances IL-6 secretion by stimulated endothelial cells," Cryobiology, vol. 57, no. 3, pp. 216-222, 2008.

[41] I. T. Sutcliffe, H. A. Smith, D. Stanimirovic, and J. S. Hutchison, "Effects of moderate hypothermia on IL-1 beta-induced leukocyte rolling and adhesion in pial microcirculation of mice and on proinflammatory gene expression in human cerebral endothelial cells," Journal of Cerebral Blood Flow and Metabolism, vol. 21, no. 11, pp. 1310-1319, 2001.

[42] L. X. Li, T. Jiang, E. Z. Liu et al., "Effect of intraischemic mild hypothermia on interleukin-1beta and monocyte chemoattractant protein-1 contents in ischemic core of rat cortex after transient focal cerebral ischemia," Zhonghua Yi Xue Za Zhi, vol. 83, no. 7, pp. 541-543, 2003.

[43] C. W. Callaway, J. C. Rittenberger, E. S. Logue, and M. J. McMichael, "Hypothermia after cardiac arrest does not alter serum inflammatory markers," Critical Care Medicine, vol. 36, no. 9, pp. 2607-2612, 2008.

[44] F. Hildebrand, M. van Griensven, P. Giannoudis et al., "Effects of hypothermia and re-warming on the inflammatory response in a murine multiple hit model of trauma," Cytokine, vol. 31, no. 5, pp. 382-393, 2005.

[45] R. Eggum, T. Ueland, T. E. Mollnes et al., "Perfusion temperature, thyroid hormones and inflammation during pediatric cardiac surgery," Interactive Cardiovascular and Thoracic Surgery, vol. 10, no. 1, pp. 76-80, 2010.

[46] P. Menasche, J. Peynet, N. Haeffner-Cavaillon et al., "Influence of temperature on neutrophil trafficking during clinical cardiopulmonary bypass," Circulation, vol. 92, no. 9, pp. II334-II340, 1995.

[47] T. L. Haddix, T. H. Pohlman, R. F. Noel, T. T. Sato, E. M. Boyle Jr., and E. D. Verrier, "Hypothermia inhibits human E-selectin transcription," Journal of Surgical Research, vol. 64, no. 2, pp. 176-183, 1996.

[48] D. Frohlich, S. Wittmann, G. Rothe, D. I. Sessler, P. Vogel, and K. Taeger, "Mild hyperthermia down-regulates receptor-dependent neutrophil function," Anesthesia and Analgesia, vol. 99, no. 1, pp. 284-292, 2004.

[49] M. Johnson, T. Haddix, T. Pohlman, and E. D. Verrier, "Hypothemia reversibly inhibits endothelial cell expression of Eselectin and tissue factor," Journal of Cardiac Surgery, vol. 10, no. 4, pp. 428-435, 1995.

[50] G. J. Wang, H. Y. Deng, C. M. Maier, G. H. Sun, and M. A. Yenari, "Mild hypothermia reduces ICAM-1 expression, neutrophil infiltration and microglia/monocyte accumulation following experimental stroke," Neuroscience, vol. 114, no. 4, pp. 1081-1090, 2002.

[51] H. Deng, H. S. Han, D. Cheng, G. H. Sun, and M. A. Yenari, "Mild hypothermia inhibits inflammation after experimental stroke and brain inflammation," Stroke, vol. 34, no. 10, pp. 2495-2501, 2003.

[52] C. Hanusch, K. Nowak, I. S. Gill et al., "Hypothermic preservation of lung allograft inhibits cytokine-induced chemoattractant-1, endothelial leucocyte adhesion molecule, vascular cell adhesion molecule-1 and intracellular adhesion molecule-1 expression," Clinical and Experimental Immunology, vol. 149, no. 2, pp. 364-371, 2007.

[53] J. S. Choi, J. Park, K. Suk, C. Moon, Y. K. Park, and H. S. Han, "Mild hypothermia attenuates intercellular adhesion molecule-1 induction via activation of extracellular signal-regulated kinase-1/2 in a focal cerebral ischemia model," Stroke Research and Treatment, vol. 2011, Article ID 846716, 9 pages, 2011.

[54] J. Boldt, C. Osmer, L. C. Linke, G. Gorlach, and G. Hempelmann, "Hypothermic versus normothermic cardiopulmonary bypass: Influence on circulating adhesion molecules," Journal of Cardiothoracic and Vascular Anesthesia, vol. 10, no. 3, pp. 342-347, 1996. 
[55] T. Toyoda, S. Suzuki, N. F. Kassell, and K. S. Lee, "Intraischemic hypothermia attenuates neutrophil infiltration in the rat neocortex after focal ischemia-reperfusion injury," Neurosurgery, vol. 39, no. 6, pp. 1200-1205, 1996.

[56] B. Duz, M. Kaplan, S. Bilgic, A. Korkmaz, and S. Kahraman, "Does hypothermic treatment provide an advantage after spinal cord injury until surgery? An experimental study," $\mathrm{Ne}$ urochemical Research, vol. 34, no. 3, pp. 407-410, 2009.

[57] K. Chatzipanteli, Y. Yanagawa, A. E. Marcillo, S. Kraydieh, R. P. Yezierski, and W. D. Dietrich, "Posttraumatic hypothermia reduces polymorphonuclear leukocyte accumulation following spinal cord injury in rats," Journal of Neurotrauma, vol. 17, no. 4, pp. 321-332, 2000.

[58] T. J. Grezzana Filho, T. B. Mendonça, G. Gabiatti, C. D. Kruel, and C. O. Corso, "Topic liver hypothermia and ischemic preconditioning. A new model of ischemia and reperfusion in rats," Acta Cirurgica Brasileira, vol. 24, no. 4, pp. 262-266, 2009.

[59] S. F. Hsu, K. C. Niu, C. L. Lin, and M. T. Lin, "Brain cooling causes attenuation of cerebral oxidative stress, systemic inflammation, activated coagulation, and tissue ischemia/injury during heatstroke," Shock, vol. 26, no. 2, pp. 210 220, 2006.

[60] J. Yuan and B. A. Yankner, "Apoptosis in the nervous system," Nature, vol. 407, no. 6805, pp. 802-809, 2000.

[61] H. Wajant, "The Fas signaling pathway: more than a paradigm,” Science, vol. 296, no. 5573, pp. 1635-1636, 2002.

[62] P. Li, D. Nijhawan, and X. Wang, "Mitochondrial activation of apoptosis," Cell, vol. 116, no. 2, pp. S57-S59, 2004.

[63] D. T. Chao and S. J. Korsmeyer, "BCL-2 family: regulators of cell death," Annual Review of Immunology, vol. 16, pp. 395419, 1998.

[64] P. Li, D. Nijhawan, I. Budihardjo et al., "Cytochrome c and dATP-dependent formation of Apaf-1/caspase- 9 complex initiates an apoptotic protease cascade," Cell, vol. 91, no. 4, pp. 479-489, 1997.

[65] J. A. Fresno Vara, E. Casado, J. de Castro, P. Cejas, C. BeldaIniesta, and M. Gonzalez-Baron, "P13K/Akt signalling pathway and cancer," Cancer Treatment Reviews, vol. 30, no. 2, pp. 193-204, 2004.

[66] J. D. Langereis, H. A. Raaijmakers, L. H. Ulfman, and L. Koenderman, "Abrogation of NF-kappaB signaling in human neutrophils induces neutrophil survival through sustained p38-MAPK activation," Journal of Leukocyte Biology, vol. 88, no. 4, pp. 655-664, 2010.

[67] J. T. Povlishock, A. Buki, H. Koiziumi, J. Stone, and D. O. Okonkwo, "Initiating mechanisms involved in the pathobiology of traumatically induced axonal injury and interventions targeted at blunting their progression," Acta Neurochirurgica Supplement, vol. 73, pp. 15-20, 1999.

[68] M. Adachi, O. Sohma, S. Tsuneishi, S. Takada, and H. Nakamura, "Combination effect of systemic hypothermia and caspase inhibitor administration against hypoxic-ischemic brain damage in neonatal rats," Pediatric Research, vol. 50, no. 5, pp. 590-595, 2001.

[69] X. H. Ning, S. H. Chen, C. S. Xu et al., "Hypothermic protection of the ischemic heart via alterations in apoptotic pathways as assessed by gene array analysis," Journal of Applied Physiology, vol. 92, no. 5, pp. 2200-2207, 2002.

[70] A. K. Liou, R. S. Clark, D. C. Henshall, X. M. Yin, and J. Chen, "To die or not to die foyr neurons in ischemia, traumatic brain injury and epilepsy: a review on the stress-activated signaling pathways and apoptotic pathways," Progress in Neurobiology, vol. 69, no. 2, pp. 103-142, 2003.

[71] R. Raghupathi, D. I. Graham, and T. K. McIntosh, "Apoptosis after traumatic brain injury," Journal of Neurotrauma, vol. 17, no. 10, pp. 927-938, 2000.

[72] R. R. Leker and E. Shohami, "Cerebral ischemia and traumadifferent etiologies yet similar mechanisms: neuroprotective opportunities," Brain Research Reviews, vol. 39, no. 1, pp. 5573, 2002.

[73] A. Paunel-Gorgulu, M. Zornig, T. Logters et al., "Mcl-1mediated impairment of the intrinsic apoptosis pathway in circulating neutrophils from critically ill patients can be overcome by Fas stimulation," Journal of Immunology, vol. 183, no. 10, pp. 6198-6206, 2009.

[74] T. Fu, A. T. Blei, N. Takamura et al., "Hypothermia inhibits Fas-mediated apoptosis of primary mouse hepatocytes in culture," Cell Transplantation, vol. 13, no. 6, pp. 667-676, 2004.

[75] T. Mizuno, Y. Kannan, M. Tokunaga et al., "Role of hypothermia induced by tumor necrosis factor on apoptosis and function of inflammatory neutrophils in mice," American Journal of Physiology, vol. 278, no. 1, pp. R157-R165, 2000.

[76] Z. H. Shao, W. W. Sharp, K. R. Wojcik et al., "Therapeutic hypothermia cardioprotection via Akt- and nitric oxidemediated attenuation of mitochondrial oxidants," American Journal of Physiology, vol. 298, no. 6, pp. H2164-H2173, 2010.

[77] G. Lotocki, J. P. Rivero Vaccari, E. R. Perez et al., "Therapeutic hypothermia modulates TNFR1 signaling in the traumatized brain via early transient activation of the JNK pathway and suppression of XIAP cleavage," European Journal of Neuroscience, vol. 24, no. 8, pp. 2283-2290, 2006.

[78] H. Zhang, G. Xu, J. Zhang, S. Murong, Y. Mei, and E. Tong, "Mild hypothermia reduces ischemic neuron death via altering the expression of p53 and bcl-2," Neurological Research, vol. 32, no. 4, pp. 384-389, 2010.

[79] A. Janata and M. Holzer, "Hypothermia after cardiac arrest," Progress in Cardiovascular Diseases, vol. 52, no. 2, pp. 168179, 2009.

[80] M. Keel, E. Ecknauer, R. Stocker et al., "Different pattern of local and systemic release of proinflammatory and anti-inflammatory mediators in severely injured patients with chest trauma," Journal of Trauma, vol. 40, no. 6, pp. 907-912, 1996.

[81] M. Frink, M. van Griensven, P. Kobbe et al., "IL-6 predicts organ dysfunction and mortality in patients with multiple injuries," Scandinavian Journal of Trauma, Resuscitation and Emergency Medicine, vol. 17, article 49, 2009.

[82] M. Frink, Y. C. Hsieh, C. H. Hsieh et al., "Keratinocytederived chemokine plays a critical role in the induction of systemic inflammation and tissue damage after trauma-hemorrhage," Shock, vol. 28, no. 5, pp. 576-581, 2007.

[83] T. M. Carlos and J. M. Harlan, "Leukocyte-endothelial adhesion molecules," Blood, vol. 84, no. 7, pp. 2068-2101, 1994.

[84] J. M. Harlan, N. B. Vedder, R. K. Winn, and C. L. Rice, "Mechanisms and consequences of leukocyte-endothelial interaction," Western Journal of Medicine, vol. 155, no. 4, pp. 365-369, 1991.

[85] U. H. Von Andrian, P. Hansell, J. D. Chambers et al., "L-selectin function is required for beta2-integrin-mediated neutrophil adhesion at physiological shear rates in vivo," American Journal of Physiology, vol. 263, no. 4, pp. H1034-H1044, 1992. 
[86] A. Kimura, S. Sakurada, H. Ohkuni, Y. Todome, and K. Kurata, "Moderate hypothermia delays proinflammatory cytokine production of human peripheral blood mononuclear cells," Critical Care Medicine, vol. 30, no. 7, pp. 1499-1502, 2002.

[87] E. Suehiro, H. Fujisawa, T. Akimura et al., "Increased matrix metalloproteinase- 9 in blood in association with activation of interleukin-6 after traumatic brain injury: influence of hypothermic therapy," Journal of Neurotrauma, vol. 21, no. 12, pp. 1706-1711, 2004.

[88] W. D. Dietrich, K. Chatzipanteli, E. Vitarbo, K. Wada, and K. Kinoshita, "The role of inflammatory processes in the pathophysiology and treatment of brain and spinal cord trauma," Acta Neurochirurgica, vol. 89, pp. 69-74, 2004.

[89] W. D. Dietrich, R. Busto, M. Y. Globus, and M. D. Ginsberg, "Brain damage and temperature: cellular and molecular mechanisms," Advances in Neurology, vol. 71, pp. 177-194, 1996.

[90] O. I. Schmidt, C. E. Heyde, W. Ertel, and P. F. Stahel, "Closed head injury-an inflammatory disease?" Brain Research Reviews, vol. 48, no. 2, pp. 388-399, 2005.

[91] V. C. Asensio and I. L. Campbell, "Chemokines in the CNS: plurifunctional mediators in diverse states," Trends in Neurosciences, vol. 22, no. 11, pp. 504-512, 1999.

[92] J. E. Merrill and E. N. Benveniste, "Cytokines in inflammatory brain lesions: helpful and harmful," Trends in Neurosciences, vol. 19, no. 8, pp. 331-338, 1996.

[93] M. C. Morganti-Kossmann, M. Rancan, P. F. Stahel, and T. Kossmann, "Inflammatory response in acute traumatic brain injury: a double-edged sword," Current Opinion in Critical Care, vol. 8, no. 2, pp. 101-105, 2002.

[94] R. J. Schoettle, P. M. Kochanek, M. J. Magargee, M. W. Uhl, and E. M. Nemoto, "Early polymorphonuclear leukocyte accumulation correlates with the development of posttraumatic cerebral edema in rats," Journal of Neurotrauma, vol. 7, no. 4, pp. 207-217, 1990.

[95] H. C. Patel, H. Boutin, and S. M. Allan, "Interleukin-1 in the brain: mechanisms of action in acute neurodegeneration," Annals of the New York Academy of Sciences, vol. 992, pp. 3947, 2003.

[96] S. M. Allan, L. C. Parker, B. Collins, R. Davies, G. N. Luheshi, and N. J. Rothwell, "Cortical cell death induced by IL-1 is mediated via actions in the hypothalamus of the rat," Proceedings of the National Academy of Sciences of the United States of America, vol. 97, no. 10, pp. 5580-5585, 2000.

[97] M. Buttini, A. Sauter, and H. W. Boddeke, "Induction of interleukin-1beta mRNA after focal cerebral ischaemia in the rat," Molecular Brain Research, vol. 23, no. 1-2, pp. 126-134, 1994.

[98] C. A. Davies, S. A. Loddick, S. Toulmond, R. P. Stroemer, J. Hunt, and N. J. Rothwell, "The progression and topographic distribution of interleukin-1beta expression after permanent middle cerebral artery occlusion in the rat," Journal of Cerebral Blood Flow and Metabolism, vol. 19, no. 1, pp. 87-98, 1999.

[99] V. L. Pearson, N. J. Rothwell, and S. Toulmond, "Excitotoxic brain damage in the rat induces interleukin-1beta protein in microglia and astrocytes: correlation with the progression of cell death," Glia, vol. 25, no. 4, pp. 311-323, 1999.

[100] K. Yabuuchi, M. Minami, S. Katsumata, and M. Satoh, "In situ hybridization study of interleukin-1beta mRNA induced by kainic acid in the rat brain," Brain Research Molecular Brain Research, vol. 20, no. 1-2, pp. 153-161, 1993.
[101] C. B. Lawrence, S. M. Allan, and N. J. Rothwell, "Interleukin1beta and the interleukin-1 receptor antagonist act in the striatum to modify excitotoxic brain damage in the rat," European Journal of Neuroscience, vol. 10, no. 3, pp. 11881195, 1998.

[102] S. A. Loddick and N. J. Rothwell, "Neuroprotective effects of human recombinant interleukin-1 receptor antagonist in focal cerebral ischaemia in the rat," Journal of Cerebral Blood Flow and Metabolism, vol. 16, no. 5, pp. 932-940, 1996.

[103] J. K. Relton and N. J. Rothwell, "Interleukin-1 receptor antagonist inhibits ischaemic and excitotoxic neuronal damage in the rat," Brain Research Bulletin, vol. 29, no. 2, pp. 243-246, 1992.

[104] A. L. Betz, G. P. Schielke, and G. Y. Yang, "Interleukin-1 in cerebral ischemia," Keio Journal of Medicine, vol. 45, no. 3, pp. 230-237, 1996.

[105] R. P. Stroemer and N. J. Rothwell, "Cortical protection by localized striatal injection of IL-1ra following cerebral ischemia in the rat," Journal of Cerebral Blood Flow and Metabolism, vol. 17, no. 6, pp. 597-604, 1997.

[106] S. A. Loddick, A. MacKenzie, and N. J. Rothwell, "An ICE inhibitor, z-VAD-DCB attenuates ischaemic brain damage in the rat," NeuroReport, vol. 7, no. 9, pp. 1465-1468, 1996.

[107] K. D. Fairchild, R. M. Viscardi, L. Hester, I. S. Singh, and J. D. Hasday, "Effects of hypothermia and hyperthermia on cytokine production by cultured human mononuclear phagocytes from adults and newborns," Journal of Interferon and Cytokine Research, vol. 20, no. 12, pp. 1049-1055, 2000.

[108] A. Diestel, S. Troeller, N. Billecke, I. M. Sauer, F. Berger, and K. R. L. Schmitt, "Mechanisms of hypothermia-induced cell protection mediated by microglial cells in vitro," European Journal of Neuroscience, vol. 31, no. 5, pp. 779-787, 2010.

[109] T. Matsui, T. Ishikawa, H. Takeuchi, K. Okabayashi, and T. Maekawa, "Mild hypothermia promotes pro-inflammatory cytokine production in monocytes," Journal of Neurosurgical Anesthesiology, vol. 18, no. 1, pp. 32-36, 2006.

[110] R. Kentner, F. M. Rollwagen, S. Prueckner et al., "Effects of mild hypothermia on survival and serum cytokines in uncontrolled hemorrhagic shock in rats," Shock, vol. 17, no. 6, pp. 521-526, 2002.

[111] Z. Chen, H. Chen, P. Rhee et al., "Induction of profound hypothermia modulates the immune/inflammatory response in a swine model of lethal hemorrhage," Resuscitation, vol. 66, no. 2, pp. 209-216, 2005.

[112] P. Vaagenes, Y. Gundersen, and P. K. Opstad, "Rapid rewarming after mild hypothermia accentuates the inflammatory response after acute volume controlled haemorrhage in spontaneously breathing rats," Resuscitation, vol. 58, no. 1, pp. 103-112, 2003.

[113] M. Qing, A. Nimmesgern, P. C. Heinrich et al., "Intrahepatic synthesis of tumor necrosis factor-alpha related to cardiac surgery is inhibited by interleukin-10 via the Janus kinase (Jak)/signal transducers and activator of transcription (STAT) pathway," Critical Care Medicine, vol. 31, no. 12, pp. 2769-2775, 2003.

[114] O. Huet, B. Kinirons, L. Dupic et al., "Induced mild hypothermia reduces mortality during acute inflammation in rats," Acta Anaesthesiologica Scandinavica, vol. 51, no. 9, pp. 1211-1216, 2007.

[115] K. H. Polderman, "Mechanisms of action, physiological effects, and complications of hypothermia," Critical Care Medicine, vol. 37, no. 7, pp. S186-S202, 2009. 
[116] K. Chatzipanteli, O. F. Alonso, S. Kraydieh, and W. D. Dietrich, "Importance of posttraumatic hypothermia and hyperthermia on the inflammatory response after fluid percussion brain injury: biochemical and immunocytochemical studies," Journal of Cerebral Blood Flow and Metabolism, vol. 20, no. 3, pp. 531-542, 2000.

[117] G. Thomas and P. S. Sousa, "Early inflammatory response to carrageenan in the pleural cavity and paw of rats with altered body temperature," Journal of Pharmacy and Pharmacology, vol. 38, no. 12, pp. 936-938, 1986.

[118] A. Wladis, R. G. Hahn, B. Brismar, and B. T. Kjellström, "Effects of induced hypothermia after soft-tissue injury," Archives of Orthopaedic and Trauma Surgery, vol. 124, no. 4, pp. 243-249, 2004.

[119] W. D. Biggar, C. Barker, D. Bohn, and G. Kent, "Partial recovery of neutrophil functions during prolonged hypothermia in pigs," Journal of Applied Physiology, vol. 60, no. 4, pp. 11861189, 1986.

[120] X. Wu, J. Stezoski, P. Safar et al., "Mild hypothermia during hemorrhagic shock in rats improves survival without significant effects on inflammatory responses," Critical Care Medicine, vol. 31, no. 1, pp. 195-202, 2003.

[121] L. Liu and M. A. Yenari, "Therapeutic hypothermia: neuroprotective mechanisms," Frontiers in Bioscience, vol. 12, no. 3, pp. 816-825, 2007.

[122] Y. Koda, R. Tsuruta, M. Fujita et al., "Moderate hypothermia suppresses jugular venous superoxide anion radical, oxidative stress, early inflammation, and endothelial injury in forebrain ischemia/reperfusion rats," Brain Research, vol. 1311, pp. 197-205, 2010.

[123] T. A. Novack, M. C. Dillon, and W. T. Jackson, "Neurochemical mechanisms in brain injury and treatment: a review," Journal of Clinical and Experimental Neuropsychology, vol. 18, no. 5, pp. 685-706, 1996.

[124] B. Halliwell, "Reactive oxygen species and the central nervous system," Journal of Neurochemistry, vol. 59, no. 5, pp. 16091623, 1992.

[125] C. L. Robertson, L. Soane, Z. T. Siegel, and G. Fiskum, "The potential role of mitochondria in pediatric traumatic brain injury," Developmental Neuroscience, vol. 28, no. 4-5, pp. 432446, 2006.

[126] P. G. Sullivan, J. E. Springer, E. D. Hall, and S. W. Scheff, "Mitochondrial uncoupling as a therapeutic target following neuronal injury," Journal of Bioenergetics and Biomembranes, vol. 36, no. 4, pp. 353-356, 2004.

[127] A. Merenda and R. Bullock, "Clinical treatments for mitochondrial dysfunctions after brain injury," Current Opinion in Critical Care, vol. 12, no. 2, pp. 90-96, 2006.

[128] H. Bayir, P. D. Adelson, S. R. Wisniewski et al., "Therapeutic hypothermia preserves antioxidant defenses after severe traumatic brain injury in infants and children," Critical Care Medicine, vol. 37, no. 2, pp. 689-695, 2009.

[129] M. Y. Globus, R. Busto, B. Lin, H. Schnippering, and M. D. Ginsberg, "Detection of free radical activity during transient global ischemia and recirculation: effects of intraischemic brain temperature modulation," Journal of Neurochemistry, vol. 65, no. 3, pp. 1250-1256, 1995.

[130] R. J. Dempsey, D. J. Combs, and M. Edwards Maley, "Moderate hypothermia reduces postischemic edema development and leukotriene production," Neurosurgery, vol. 21, no. 2, pp. 177-181, 1987.

[131] A. Mrlian, M. Smrcka, and M. Klabusay, "The use of controlled mild hypothermia and immune system status in patients with severe brain injury," Bratislavské Lekárske Listy, vol. 107, no. 4, pp. 113-117, 2006.

[132] R. Busto, W. D. Dietrich, M. Y. Globus, I. Valdes, P. Scheinberg, and M. D. Ginsberg, "Small differences in intraischemic brain temperature critically determine the extent of ischemic neuronal injury," Journal of Cerebral Blood Flow and Metabolism, vol. 7, no. 6, pp. 729-738, 1987.

[133] J. Kang, H. Albadawi, P. J. Casey et al., "The effects of systemic hypothermia on a murine model of thoracic aortic ischemia reperfusion," Journal of Vascular Surgery, vol. 52, no. 2, pp. 435-443, 2010.

[134] T. Horiuchi, M. Kawaguchi, N. Kurita et al., "The long-term effects of mild to moderate hypothermia on gray and white matter injury after spinal cord ischemia in rats," Anesthesia and Analgesia, vol. 109, no. 2, pp. 559-566, 2009.

[135] R. Ward, N. Souder, D. Stahl et al., "The role of nitric oxide synthase and heme oxygenase in the protective effect of hypothermia in ischemia-reperfusion injury," Journal of Bone and Joint Surgery American, vol. 91, no. 11, pp. 2637-2645, 2009.

[136] R. J. Santora, M. L. Lie, D. N. Grigoryev, O. Nasir, F. A. Moore, and H. T. Hassoun, "Therapeutic distant organ effects of regional hypothermia during mesenteric ischemiareperfusion injury," Journal of Vascular Surgery, vol. 52, no. 4, pp. 1003-1014, 2010.

[137] S. Patel, H. L. Pachter, H. Yee, J. D. Schwartz, S. G. Marcus, and P. Shamamian, "Topical hepatic hypothermia attenuates pulmonary injury after hepatic ischemia and reperfusion," Journal of the American College of Surgeons, vol. 191, no. 6, pp. 650-656, 2000.

[138] P. Alderson, C. Gadkary, and D. F. Signorini, "Therapeutic hypothermia for head injury," Cochrane Database of Systematic Reviews, no. 4, Article ID CD001048, 2004.

[139] C. S. Gadkary, P. Alderson, and D. F. Signorini, "Therapeutic hypothermia for head injury," Cochrane Database of Systematic Reviews, no. 1, Article ID CD001048, 2002.

[140] O. A. Harris, J. M. Colford Jr., M. C. Good, and P. G. Matz, "The role of hypothermia in the management of severe brain injury: a meta-analysis," Archives of Neurology, vol. 59, no. 7, pp. 1077-1083, 2002.

[141] W. R. Henderson, V. K. Dhingra, D. R. Chittock, J. C. Fenwick, and J. J. Ronco, "Hypothermia in the management of traumatic brain injury: a systematic review and metaanalysis," Intensive Care Medicine, vol. 29, no. 10, pp. 16371644, 2003.

[142] L. A. McIntyre, D. A. Fergusson, P. C. Hebert, D. Moher, and J. S. Hutchison, "Prolonged therapeutic Hypothermia after traumatic brain injury in adults: a systematic review," Journal of the American Medical Association, vol. 289, no. 22, pp. 2992-2999, 2003.

[143] S. L. Bratton, R. M. Chestnut, J. Ghajar et al., "Guidelines for the management of severe traumatic brain injury. III. Prophylactic hypothermia," Journal of Neurotrauma, vol. 24, supplement 1, pp. S21-S25, 2007.

[144] S. Kanemoto, M. Matsubara, M. Noma et al., "Mild hypothermia to limit myocardial ischemia-reperfusion Injury: importance of timing," Annals of Thoracic Surgery, vol. 87, no. 1, pp. 157-163, 2009.

[145] J. T. Povlishock and E. P. Wei, "Posthypothermic rewarming considerations following traumatic brain injury," Journal of Neurotrauma, vol. 26, no. 3, pp. 333-340, 2009.

[146] K. Kim, Y. H. Jo, J. E. Rhee et al., "Effect of speed of rewarming and administration of anti-inflammatory or anti-oxidant agents on acute lung injury in an intestinal ischemia model 
treated with therapeutic hypothermia," Resuscitation, vol. 81, no. 1, pp. 100-105, 2010.

[147] J. P. Nolan, C. D. Deakin, J. Soar, B. W. Bottiger, and G. Smith, "European resuscitation council guidelines for resuscitation 2005: section 4. Adult advanced life support," Resuscitation, vol. 67, suppl. 1, pp. S39-S86, 2005. 


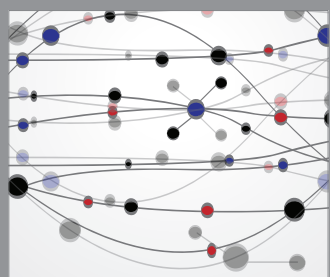

The Scientific World Journal
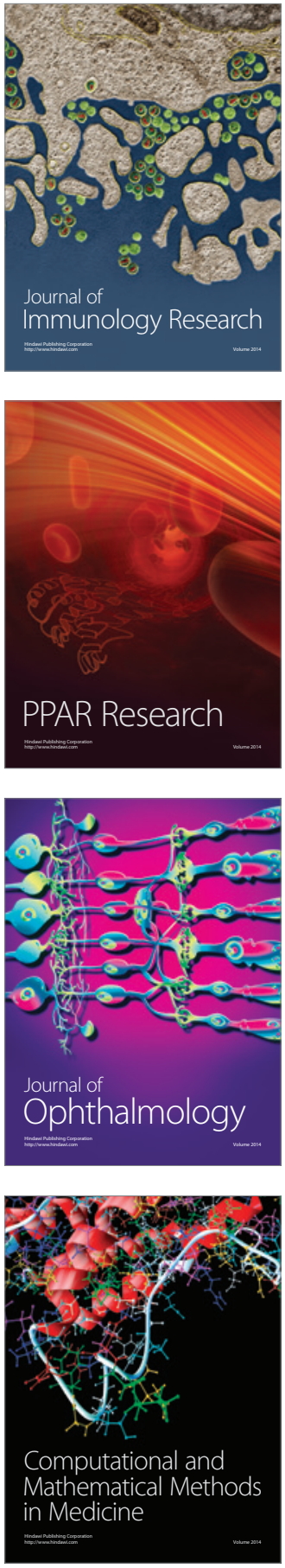

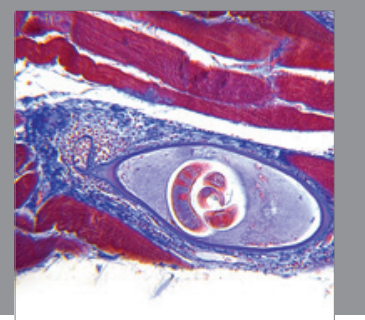

Gastroenterology

Research and Practice
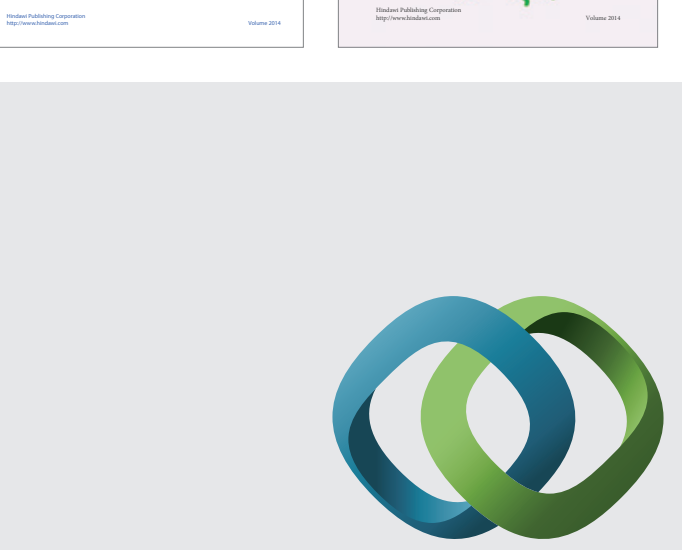

\section{Hindawi}

Submit your manuscripts at

http://www.hindawi.com
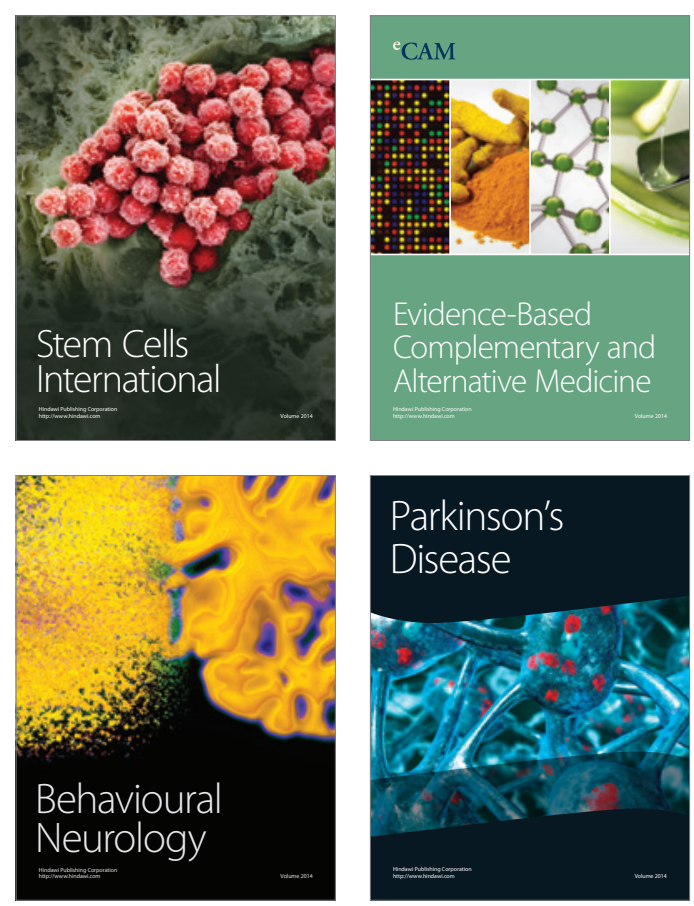

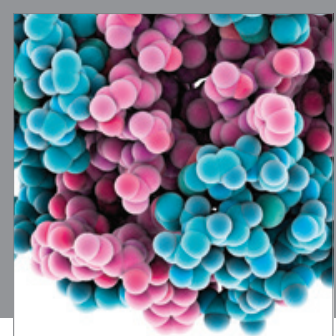

Journal of
Diabetes Research

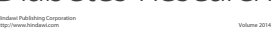

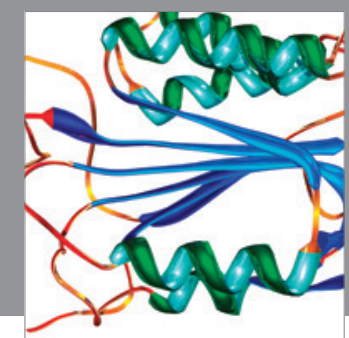

Disease Markers
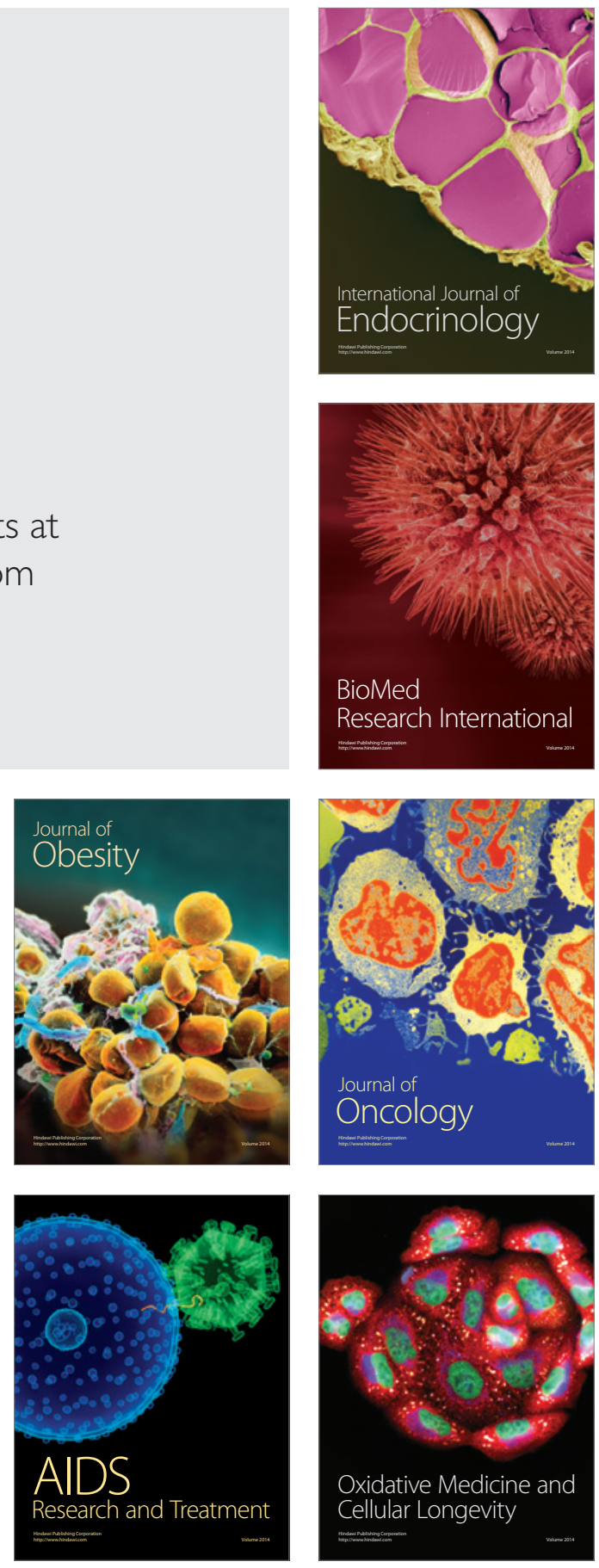